\title{
Progressive effects of shading on experimental wetland communities over three years
}

\section{Journal Article}

Author(s):

Edelkraut, Kirsten A.; Güsewell, Sabine

Publication date:

2006-04

Permanent link:

https://doi.org/10.3929/ethz-b-000413196

Rights / license:

In Copyright - Non-Commercial Use Permitted

Originally published in:

Plant Ecology 183(2), https://doi.org/10.1007/s11258-005-9042-y 


\title{
Progressive effects of shading on experimental wetland communities over three years
}

\author{
Kirsten A. Edelkraut* and Sabine Güsewell \\ Geobotanical Institute ETH Zürich, Universitätsstrasse 18, ETH Zentrum CHN G 28.2, CH-8092 Zürich, \\ Switzerland; *Author for correspondence (e-mail: kirsten.edelkraut@env.ethz.ch; phone: +41-1-632-8635; \\ fax: + 41-1-632-1215)
}

Received 7 April 2004; accepted in revised form 8 August 2005

Key words: Community structure, Diversity, Morphological plasticity, Seasonal light availability, Shade, Succession, Wetland vegetation

\begin{abstract}
To investigate how the composition of wetland communities changes over time in response to altered light regimes, experimental communities of five Carex and four grass species were subjected to artificial shading (continuous or seasonal) in a three-year field experiment. Shoot number and size was measured after six weeks, and shoot biomass was harvested five times during the experiment. Communities were initially dominated by three grass species in all treatments, but subsequently, the Carex species increased and reached dominance in the control plots, whereas grasses remained dominant in the shaded plots. Shading had no effect on the biomass of communities or of single species in the first year. In the second year, community biomass was still unaffected, but shading reduced the biomass of three Carex species and also reduced species diversity. In the third year, shading reduced community biomass and all Carex species, but not species diversity. The greater shade tolerance of the grasses could not be explained by differences in morphological plasticity: after six weeks of growth all species had increased shoot height in response to shade by $40-70 \%$. Grasses were hardly more plastic than Carex species. We propose that the long-term success of the Carex species in full light was due to a high allocation of biomass to belowground parts, which may have reduced losses caused by repeated harvesting of shoots (a simulation of management in productive wet meadows). Shading probably caused the Carex plants to change their allocation pattern, and thus prevented their progressive increase.
\end{abstract}

\section{Introduction}

Light limitation is often considered to be the mechanism excluding slow-growing, small plant species from productive or unmanaged grassland vegetation (e.g. Foster and Gross 1998; Jensen and Schrautzer 1999; Zobel 2001), though few studies have directly investigated how species coexistence in grasslands depends on light availability. In dense and tall vegetation, light limitation is caused by the plant canopy itself, which creates a vertical light gradient (Hirose and Werger 1995; Anten and Hirose 1999; Schieving and Poorter 1999). The persistence of species in the lower canopy layers depends on their ability to tolerate low-light conditions, or to grow during periods with greater light availability (Yoshie 1995; Stuefer and Huber 1998).

Relationships between species composition and light conditions within the canopy along 
productivity gradients do not accurately indicate the role of light availability for species coexistence because along these gradients, changes in light intensity are associated with changes in vertical light distribution and in below-ground competition (Belcher et al. 1995). To determine the role played by light availability in itself, experiments must directly manipulate light by shading or additional illumination (Weihe and Neely 1997; Edelkraut and Güsewell 2001). The few field experiments performed so far have shown rather weak effects of changed light availability on established vegetation (Eek and Zobel 1997; Spacková et al. 1998; Güsewell and Edwards 1999; Liira and Zobel 2000; Rajaniemi 2002). However, these results mainly stem from one-year experiments. Longer lasting experiments showed that improving light supply through the removal of dominant tall species only had significant effects on the remaining vegetation after several years (Keddy 1989; Leps 1999). It may therefore be expected that the effects of artificial shading or illumination on plant species composition will also take time to appear.

The effects of light supply on species coexistence are also likely to depend on temporal variation in light supply. Short-term fluctuations in light intensity are known to be of great importance for plants in the understory of forests (Sims and Pearcy 1993). In herbaceous vegetation, light conditions for short species typically deteriorate over the course of the growing season as tall dominant species build up their canopy (Wheeler and Shaw 1991; Güsewell and Edwards 1999). The first part of the growing season is therefore of particular importance for the growth of short species (Anten and Hirose 1999), which might be particularly sensitive to shading during this important period (Foster 2000), whereas late-seasonal shading would be expected to have a smaller effect (Güsewell 1997). In contrast, tall species can compete for light during the whole growing season and should therefore be affected similarly by additional shading in early or late season. Shading in late season might even affect tall species more than short species because the investment in tall supporting structures and large leaf area might not pay off if the whole plant suddenly becomes shaded (Henry and Aarssen 1997; Schieving and Poorter 1999). However, these seasonal effects have not yet been demonstrated experimentally.
This study investigates how experimental communities of nine perennial plant speciesrespond to various shading regimes (continuous or seasonal) over a period of three years. We expected that shading would reduce aboveground biomass and modify the species composition of the developing wetland communities. Our aim was to test (1) whether this influence increases with time, (2) whether this influence depends on the temporal pattern of shading and (3) whether species that normally occur only in unshaded, low-productive fen vegetation are reduced disproportionately by shading, especially by shading early in the season. Finally, we examined whether there was a correspondence between shade tolerance and morphological plasticity in response to shade among the nine species.

\section{Methods}

\section{Field plots}

The experiment was established on an abandoned arable field on peat soil near lake 'Hasensee' in Thurgau, Northern Switzerland (coordinates (m): 704331/274088). The site is a glacial basin of around 300 ha, in which peat soils have developed over an impermeable layer of lake marl. In the mid 1940s, the area was drained for agriculture, which led to rapid mineralization of the peat. The resulting peat loss caused the groundwater table to remain fairly high; even in dry periods, it is not more than $60-80 \mathrm{~cm}$ below soil surface. At the experimental site, the peat layer was approximately $1 \mathrm{~m}$ deep.

Twenty $1 \mathrm{~m}^{2}$ plots were established in April 2000. To reduce the nutrient load of the soil and create wetter conditions, $30 \mathrm{~cm}$ of topsoil were removed from each plot and replaced by $20 \mathrm{~cm}$ of peat originating from deeper soil layers. The latter was obtained by removing the uppermost $30 \mathrm{~cm}$ of soil from neighbouring plots and transferring the underlying peat to the experimental plots, where it was homogenized and leveled. Each experimental plot was surrounded by a plastic sheet $30 \mathrm{~cm}$ in height, which was driven $25-30 \mathrm{~cm}$ deep in the soil to prevent lateral nutrient inflow. To monitor the groundwater level, a perforated plastic tube of $1 \mathrm{~m}$ length was installed in each plot. The entire experimental site was fenced. 
To assess within-site variation in soil conditions, soil cores $(0-10 \mathrm{~cm}$ depth, $3 \mathrm{~cm}$ diameter) were taken in May 2000 and September 2001 at three random points from each plot, pooled, stored cool for transport and air-dried in the greenhouse. Total soil nitrogen was determined in dried and sieved samples from May 2000 by Kjeldahl digestion $\left(1 \mathrm{~h}\right.$ at $420{ }^{\circ} \mathrm{C}$ with $98 \% \mathrm{H}_{2} \mathrm{SO}_{4}$ and a copper sulphate-titanium oxide catalyst) of a $0.5 \mathrm{~g}$ subsample. Digests were analysed colometrically on a Flow Injection Analyser (Tectator, HÖGANÄS). Extractable $\mathrm{NO}_{3}-\mathrm{N}$ was determined from samples collected in September 2001 by shaking $5 \mathrm{~g}$ air dried soil in $50 \mathrm{ml}$ distilled water for $1 \mathrm{~h}$; extracts were analysed colometrically (FIA, Tectator). Soil $\mathrm{pH}$ was determined at both dates from a $10 \mathrm{~g}$ soil sample suspended in $25 \mathrm{ml}$ of $0.01 \mathrm{M} \mathrm{CaCl}$. Groundwater level was measured weekly during the growing seasons.

\section{Plant species}

The experimental mixtures consisted of five Carex and four grass species (Table 1). All species occur in base-rich wetlands but at sites with differing nutrient availability (Table 1).

Cuttings of the five Carex species were gathered from different field sites on the Northern Swiss Plateau in summer 1998 or 1999 and cultivated in the garden of the Geobotanical Institute in Zurich.

Table 1. Plant species used for the experiment and their ecological indicator values (Landolt 1977) for soil nutrients (N) and light (L).

\begin{tabular}{lll}
\hline Species & \multicolumn{2}{l}{ Indicator values } \\
\cline { 2 - 3 } & $\mathrm{N}$ & $\mathrm{L}$ \\
\hline Carex davalliana Smith & 2 & 5 \\
Carex elata All. & 3 & 4 \\
Carex flacca Schreb. & 2 & 3 \\
Carex flava L. & 2 & 4 \\
Carex panicea L. & 2 & 4 \\
Agrostis canina L. & 2 & 4 \\
Anthoxanthum odoratum L. s.l. & 3 & 4 \\
Holcus lanatus L. & 3 & 4 \\
Molinia caerulea (L.) Moench & 2 & 4 \\
\hline
\end{tabular}

These indicator values describe site conditions under which species typically occur in Switzerland on a scale from 1 to 5 (for soil nutrients: $1=$ very poor and $5=$ very rich; for light: $1=$ shade tolerant $(<3 \%$ daylight $)$ and $5=$ only at full daylight $)$. Nomenclature follows Hess et al. (1991).
In February 2000, plants were split into individual shoots and further grown for six weeks in the greenhouse to obtain individuals of similar size. Individuals of different clones were mixed to assure clonal variation within same treatments.

Seeds of the four grass species were sown at the end of February 2000 in universal garden mould (HORTIMA) in the greenhouse of the Institute. Seedlings were transplanted and further grown in the greenhouse for about three weeks. For acclimatisation all young plants were kept for two more weeks in the garden of the Institute before they were brought to the field.

On 3-4 May 2000, well developed, single tillers of each species (clusters with two to four tillers of C. davalliana) were planted into the experimental plots using a Latin-square design with 81 plants per plot. Thus, each species occurred once in each line and row of the square. Spaces between neighbouring plants were $9 \mathrm{~cm}$ to ensure that competitive interactions were weak in the initial growth phase but strong once plants had become established. A border of $15 \mathrm{~cm}$ was left unplanted in each plot. After planting the plots were watered during four weeks and weeded during three months to ensure the establishment of the experimental plants.

\section{Treatments}

Shading cages were installed on 24 May 2000, three weeks after planting, when plants were likely to have established roots. Stable wooden frames were built in the field and covered with green shading cloth (ST30, HORTIMA, Hausen, Switzerland), which simulated the quantitative and qualitative changes in light availability created by a vegetation canopy. Five light regimes were applied during three consecutive growing seasons: continuous light $(\mathrm{L}=$ control), continuous shade (S), weekly alternation of light and shade (w), two months of light followed by two months of shade (LS) and two months of shade followed by two months of light (SL), each of them replicated four times in a randomised block design). Shading reduced the light intensity to $20 \%$ available daylight (one layer of cloth) for the continuous shading and $12 \%$ remaining daylight (one layer of cloth plus cloth cut into stripes) for the changing light regimes. By using different shading intensities all 
plots received the same total reduction in light availability, but distributed differently during the growing season. In the third year, shading was intensified, resulting in $12 \%$ available light for the continuous shading and 6\% available light (two layers of cloth) for the changing light regimes. The shading cloth was removed every year in September and reinstalled at the end of March of the following year.

Light intensity above the canopy was measured on a bright sunny day in August 2000 with a Decagon Sunfleck Ceptometer (Delta-T Devices LTD, Pullmann, WA, USA). Thermometers were installed in each shading treatment $30 \mathrm{~cm}$ above surface as well as pluviometers to note average daily temperature and average rainfall in each of the treatments during the experiment.

\section{Harvest and measurements}

Measurements on growth and morphological characteristics were performed on 26-28 June 2000. For each plant the number of tillers was counted and effective shoot height and shoot length were measured. Effective shoot height was defined as the vertical distance from soil surface to the third highest point of the plant in its natural position and effective shoot length as the distance from soil surface to the tip of the third longest leaf when the latter was stretched. These 'effective' measures seemed ecologically more relevant to us than the absolute maxima, which could be determined by a single extremely long leaf. Measurements of plant traits reflect initial short-term responses of the species to either full light (treatments L and LS) or to $20 \%$ light availability (treatments S or SL) or to weekly fluctuating light.

Shoot biomass was harvested five times during the experiment: (1) 12 September 2000, (2) 24 June 2001, (3) 24 August 2001, (4) 26 June 2002, and (5) on 10 September 2002. At each harvest shoots were cut $5 \mathrm{~cm}$ above soil surface and sorted to species, except in August 2001, when due to weather conditions plant species were separated in the laboratory and could only be differentiated by species groups (Carex vs. grasses). Shoots from the outer $20 \mathrm{~cm}$ of the plot area were harvested separately, and their biomass was discarded to avoid edge effects. Biomass was dried to a constant weight for $48 \mathrm{~h}$ at $75^{\circ} \mathrm{C}$ and weighed.

\section{Data analysis}

Shoot biomass data from each harvest were used to determine community biomass (sum of all species) and the biomass of species groups (Carex vs. grasses). These values were log-transformed to obtain normally distributed data and homogeneous error variance (Levene test). The biomass of single species (log-transformed) was analysed for the first harvest of each year, i.e. September 2000, June 2001 and June 2002, when plants had grown for approximately equal periods of time. To detect dominance patterns we also calculated Simpson's diversity Index as $1 / \sum p_{i}^{2}$, with $p_{i}=$ relative frequency of each of the nine species in a plot .

The effects of light treatments on community shoot biomass, on the ratio between the two species groups and on Simpson's index were analysed with two-way ANOVA (factors 'light' and 'block') for each of the five harvests. Treatment effects on individual species were analysed using multivariate analysis of variance (MANOVA) with the identity' response function. This analysis accounts for the interdependence of species data from the same plots. Wilk's Lambda test was used to determine the significance of treatment effects. Both wholemodel tests and separate tests for each species were considered. The effects of light treatments ( $\mathrm{L}$ and LS versus S and SL) on plant traits in June 2000 were analysed using two-way ANOVA. All calculations were performed with the statistical package JMP version 5.0 1989-2002 (SAS Institute Inc.).

\section{Results}

\section{Overall successional pattern}

Young plants established successfully, as only 12 plants out of 1620 died until June 2000, and 58 plants until September 2000. The total cover of the vegetation remained below $100 \%$ in the first year but quickly reached $100 \%$ in spring 2001, and plants, especially Holcus and Anthoxanthum, reached $80 \mathrm{~cm}$ height. This reduced light intensity at the soil surface to less than $10 \%$ of daylight, even in the unshaded plots.

Community shoot biomass at the first harvest of each year increased from $179 \mathrm{~g} \mathrm{~m}^{-2}$ in September 2000 to $256 \mathrm{~g} \mathrm{~m}^{-2}$ in June 2001 and $269 \mathrm{~g} \mathrm{~m}^{-2}$ in 
June 2002 (means of all plots). Community biomass was on average smaller at the second harvest of each year $\left(99 \mathrm{~g} \mathrm{~m}^{-2}\right.$ in August 2001 and $167 \mathrm{~g} \mathrm{~m}^{-2}$ in September 2002). Yearly shoot production per plot increased over the three years in all light treatments, except the full shade treatment, (Figure 1a). The low biomass production in late summer 2001 was due to high rainfall, which caused some of the plots to be flooded for several weeks; these plots had particularly low biomass (Figure 1a).

Site conditions in the four experimental blocks are presented in Table 2. Due to differences in rainfall, the mean groundwater level differed considerably among the three years of the experiment: it was lower than the main rooting depth of the plants in all plots in 2000 and 2002, whereas high rainfall in 2001 caused wet to waterlogged soil conditions during several weeks of the growing season in some of the plots. 18 of the 20 plots had a similar water level; only in the two wettest plots in 2001 did the appearance of Holcus and Anthoxanthum (low stature, rapid senescence) indicate that they suffered particularly from flooding. Total soil nitrogen and $\mathrm{pH}$ varied little among blocks, whereas the nitrate concentration was lowest in the block which included the wettest plots, probably due to higher denitrification rates and the growth of algae (Table 2).
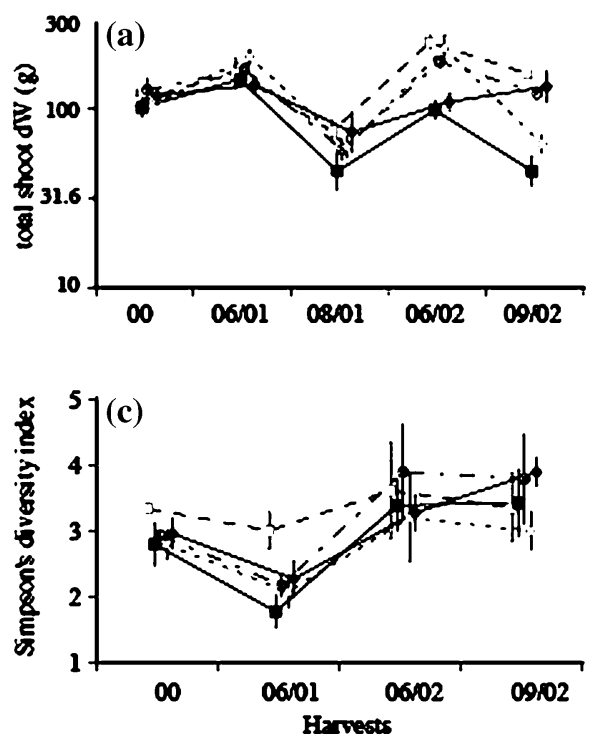

Effect of light treatments on biomass and species composition

Community shoot biomass did not respond significantly to light treatments in the first two years, whereas treatment effects were highly significant in the third year (Table 3 and Figure 1a). Shoot production was significantly higher in control plots than in continuously shaded plots (Tukey HSD $<0.05$ ) with intermediate values for the seasonally and periodically shaded plots. Light treatments also influenced the seasonal distribution of shoot production. In the treatments with seasonal shading (LS, SL), a larger fraction of the annual production occurred during the unshaded part of the season than during the shaded part. In the LS treatment, shoot biomass was therefore similar to the control treatment at the first harvest and to the shade treatment at the second harvest; in the SL treatment the pattern was opposite (Figure 1a). Furthermore, there was a greater decrease in shoot biomass between the first and second harvest of the same year with continuous shading than in control plots, meaning that shading reduced re-growth.

Community structure, i.e. the ratio of grass to Carex species, was independent of the light treatments in the first growing season (Table 3): in all treatments the grass species dominated with on
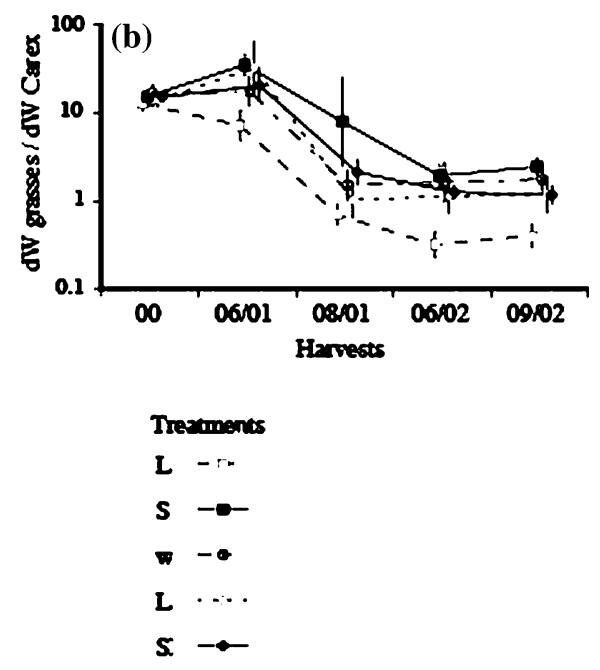

Figure 1. Effects of light treatments on temporal changes in (a) community biomass, (b) ratio of grass to Carex and (c) Simpson's index of the experimental wetland communities. Values are means $\pm \mathrm{SE}(n=4)$, shown on a lorgarithmic scale in (a) and (b). 
Table 2. Soil conditions measured at different times during the experiment.

\begin{tabular}{|c|c|c|c|c|c|c|c|}
\hline \multirow[t]{2}{*}{ Block } & \multicolumn{3}{|c|}{ Mean groundwater level $(\mathrm{cm})$} & \multicolumn{2}{|c|}{ Nitrogen $\left(\mathrm{mg} \mathrm{g}^{-1}\right.$ soil) } & \multicolumn{2}{|c|}{$\mathrm{pH}\left(\mathrm{CaCl}_{2}\right)$} \\
\hline & 2000 & 2001 & 2002 & total N 2000 & $\mathrm{NO}_{3}-\mathrm{N} 2001$ & 2000 & 2001 \\
\hline 1 & $-59.0 \pm 3.84$ & $2.6 \pm 1.02$ & $-14.9 \pm 1.18$ & $23.25 \pm 0.09$ & $0.11 \pm 0.47$ & $6.8 \pm 0.06$ & $6.3 \pm 0.03$ \\
\hline 2 & $-55.4 \pm 1.32$ & $2.3 \pm 0.98$ & $-14.9 \pm 0.49$ & $23.31 \pm 0.06$ & $0.13 \pm 0.17$ & $7.0 \pm 0.05$ & $6.3 \pm 0.01$ \\
\hline 3 & $-59.6 \pm 1.08$ & $2.1 \pm 0.26$ & $-17.5 \pm 0.24$ & $20.41 \pm 0.07$ & $0.16 \pm 0.28$ & $7.0 \pm 0.02$ & $6.4 \pm 0.02$ \\
\hline 4 & $-59.3 \pm 1.36$ & $1.2 \pm 0.21$ & $-15.3 \pm 0.67$ & $23.12 \pm 0.04$ & $0.20 \pm 0.25$ & $6.9 \pm 0.05$ & $6.2 \pm 0.05$ \\
\hline
\end{tabular}

Data are means $\pm \mathrm{SE}$ of five plots per experimental block. Differences among blocks were not significant for any of the measured variables.

Table 3. Effects of light treatments on (a) community shoot biomass (sum of all species), (b) community structure (ratio of grass biomass to Carex biomass) and (c) Simpson's diversity index (not calculated for August 2001) at each of five harvests.

\begin{tabular}{|c|c|c|c|c|c|c|}
\hline & $\mathrm{df}$ & September 2000 & June 2001 & August 2001 & June 2002 & September 2002 \\
\hline \multicolumn{7}{|c|}{ (a) Community biomass } \\
\hline Block & 3 & $0.88^{\text {n.s. }}$ & $3.14^{\text {n.s. }}$ & $0.56^{\text {n.s. }}$ & $0.24^{\text {n.s. }}$ & $0.88^{\text {n.s. }}$ \\
\hline Light & 4 & $0.66^{\text {n.s. }}$ & $1.66^{\text {n.s. }}$ & $1.09^{\text {n.s. }}$ & $10.22 * * *$ & $14.81 * * *$ \\
\hline \multicolumn{7}{|c|}{ (b) Grass/Carex ratio } \\
\hline Block & 3 & $0.27^{\text {n.s. }}$ & $3.54^{+}$ & $1.32^{\text {n.s. }}$ & $0.49^{\text {n.s. }}$ & $0.49^{+}$ \\
\hline Light & 4 & $0.19^{\text {n.s. }}$ & $2.90^{+}$ & $2.66^{+}$ & $2.67^{+}$ & $4.22 *$ \\
\hline \multicolumn{7}{|c|}{ (c) Simpson's diversity Index } \\
\hline Block & 3 & $8.29 * *$ & $22.67 * * *$ & & $0.40^{\text {n.s. }}$ & $0.49^{\text {n.s. }}$ \\
\hline Light & 4 & $2.87^{+}$ & $18.22 * * *$ & & $0.20^{\text {n.s. }}$ & $0.52^{\text {n.s. }}$ \\
\hline
\end{tabular}

Values are $F$-ratios and significance levels from ANOVA $\left({ }^{* * *}, p<0.001 ; * *, p<0.01 ;{ }^{*}, p<0.05 ;^{+}, p<0.1 ;{ }^{\text {n.s. }}, p \geq 0.1\right)$.

average 15 times more biomass than the five Carex species together (Figure 1b). In June 2001 there was a marginally significant effect of light treatments on this ratio $(p<0.1)$. Grasses were still dominant, but the grass/Carex ratio was much higher in plots with shading (17-35) than in control plots (8; Figure 1b). In 2002 the grass/Carex ratio was much smaller than in first two years and was in September significantly affected by light availability. In the control plots Carex shoot biomass even exceeded that of grasses (grass/Carex ratio $=0.4)$, whereas in the $\mathrm{S}$ - and $\mathrm{w}$-treatments grasses remained dominant (Figure 1b).

Dominance patterns of the nine plant species, as expressed by Simpson's Index $(1 / l)$, were significantly affected by light treatments only in June 2001 (Figure 1c, Table 3), showing stronger dominance of single species in the shaded plots compared to the control plots.

The effects of light on shoot biomass of individual species also increased with time. At the first harvest none of the nine species responded significantly to light treatments, whereas treatment effects were apparent at the subsequent harvests (Figure 2, Table 4). Three species (C. davalliana, C. flacca and C. flava) showed an effect in June 2001, in June
2002 this effect was only significant for C. elata, and in September 2002 the effect was significant for four of the five Carex species (marginally significant for C. davalliana, Table 4). Their biomass was generally greatest in the control treatment, intermediate with weekly changing light, and lowest with seasonal or continuous shading (Figure 2). For grass species the effect of light treatments was not significant at any time (Table 4, Figure 2).

Overall temporal patterns differed between the five Carex species on the one hand and Holcus and Anthoxanthum on the other hand. Carex species increased shoot biomass with time, especially in the control and weekly fluctuating light treatments (Figure 2a-e). This was most pronounced for Carex elata, which produced even more biomass than grasses in the third year (Figure 2b). In contrast, Anthoxanthum and Holcus had their highest shoot biomass in June 2001, after which their growth was strongly reduced (Figure $2 \mathrm{~g}, \mathrm{~h}$ ). Temporal patterns were less pronounced in $A g$ rostis and Molinia, but their responses were more similar to those of the Carex than to those of the two other grass species (Figure 2f, i). The species also differed in their ability to regenerate after the first harvest in June: while most species produced a 

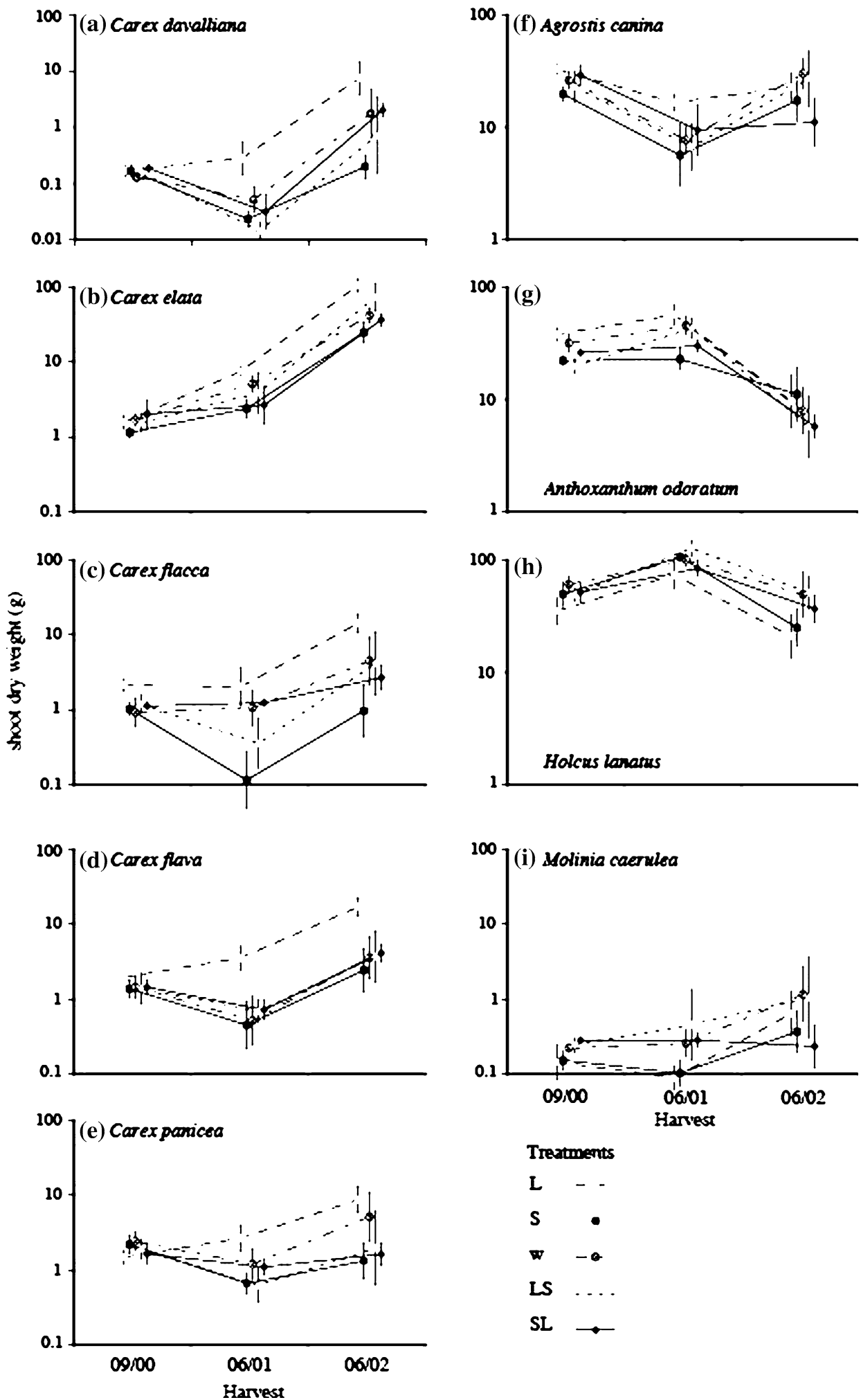

Treatments

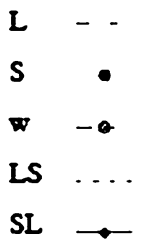

Figure 2. Effects of light treatments on temporal changes in the shoot biomass of nine plant species. data from first harvest of each year (means $\pm \mathrm{SE}, n=4$ ) are shown on a logarithmic scale. 
Table 4. Effects of light treatments on the shoot biomass of individual plant species at each of four harvests (not determined in August 2001).

\begin{tabular}{|c|c|c|c|c|}
\hline & September 2000 & June 2001 & June 2002 & September 2002 \\
\hline All species & $0.85^{\text {n.s. }}$ & $1.29^{\text {n.s. }}$ & $1.08^{\text {n.s. }}$ & $0.97^{\text {n.s. }}$ \\
\hline Carex davalliana & $0.35^{\text {n.s. }}$ & $4.28 *$ & $2.56^{+}$ & $2.99^{+}$ \\
\hline Carex elata & $0.70^{\text {n.s. }}$ & $1.89^{\text {n.s. }}$ & $3.87 *$ & $10.85^{* * *}$ \\
\hline Carex flacca & $1.64^{\text {n.s. }}$ & $3.50 *$ & $1.13^{\text {n.s. }}$ & $5.17 *$ \\
\hline Carex flava & $0.22^{\text {n.s. }}$ & $3.41 *$ & $1.29^{\text {n.s. }}$ & $5.13^{*}$ \\
\hline Carex panicea & $0.82^{\text {n.s. }}$ & $2.32^{\text {n.s. }}$ & $1.39^{\text {n.s. }}$ & $4.96^{*}$ \\
\hline Molinia caerulea & $0.96^{\text {n.s. }}$ & $1.04^{\text {n.s. }}$ & $0.66^{\text {n.s. }}$ & $0.72^{\text {n.s. }}$ \\
\hline Agrostis canina & $1.15^{\text {n.s. }}$ & $1.17^{\text {n.s. }}$ & $0.84^{\text {n.s. }}$ & $0.88^{\text {n.s. }}$ \\
\hline Anthoxanthum odoratum & $2.11^{\text {n.s. }}$ & $1.33^{\text {n.s. }}$ & $0.43^{\text {n.s. }}$ & $0.33^{\text {n.s. }}$ \\
\hline Holcus lanatus & $1.71^{\text {n.s. }}$ & $2.97^{+}$ & $1.56^{\text {n.s. }}$ & $2.58^{+}$ \\
\hline
\end{tabular}

Values are F-ratios and significance levels from MANOVA (Wilk's Lambda Test), both for all species together (overall test, denominator $\mathrm{df}=16.73$ ) and for each species separtely (denominator $\mathrm{df}=12$ ). See Table 3 for significance levels.

smaller biomass at the second harvest than at the first (cf. Figure 1a), this was not the case for C. panicea, Molinia and Agrostis, which regenerated and grew well in late summer (details not shown).

\section{Plasticity in morphological and growth traits in response to light treatments}

The indicators of growth and morphological traits measured after five weeks of treatments varied considerably among species and in response to light conditions (Table 5). The three grass species Holcus, Anthoxanthum, and Agrostis produced far more tillers than the Carex species and Molinia did; their tiller production was also more affected by the light treatments, with $30-40 \%$ fewer tillers produced in shade than in full light. The response of effective shoot height to shading was significant and similar for this three grass species, with a $40-$ $70 \%$ increase in shade (Table 5). In all treatments, the tallest species were C. elata and Holcus, and the smallest species was $C$. davalliana. Results for effective leaf length were comparable to those for effective shoot height and are therefore not shown. When light availability changed weekly, tiller production and height were intermediate between full light and continuous shade in all species (data not shown).

\section{Discussion}

\section{Effects of light treatments on community biomass}

This experiment has confirmed our hypotheses that the effects of shading on the development of wetland communities depend on the temporal

Table 5. Morphological and growth traits of individual plant species after three months of light treatments.

\begin{tabular}{|c|c|c|c|c|c|c|}
\hline \multirow[t]{2}{*}{ Species } & \multicolumn{3}{|c|}{ Number of tillers* } & \multicolumn{3}{|c|}{ Effective shoot height $(\mathrm{cm})$} \\
\hline & Light & Shade & Shade/light & Light & Shade & Shade/light \\
\hline Carex davalliana & $7.7(0.67)$ & $7.5(0.75)$ & $0.98^{\text {n.s. }}$ & $4.3(0.39)$ & $6.4(0.64)$ & $1.48^{* *}$ \\
\hline Carex elata & $2.1(0.20)$ & $1.7(0.22)$ & $0.81^{\text {n.s. }}$ & $13.2(1.39)$ & $20.0(2.45)$ & $1.51^{* * *}$ \\
\hline Carex flacca & $1.9(0.25)$ & $1.6(0.07)$ & $0.85^{+}$ & $7.1(0.48)$ & $9.8(0.41)$ & $1.38^{* *}$ \\
\hline Carex flava & $2.4(0.35)$ & $1.8(0.24)$ & $0.76^{\text {n.s. }}$ & $8.4(0.76)$ & $12.2(1.59)$ & $1.45^{*}$ \\
\hline Carex panicea & $3.2(0.24)$ & $3.1(0.28)$ & $0.98^{\text {n.s. }}$ & $10.0(1.16)$ & $14.1(1.26)$ & $1.41^{*}$ \\
\hline Molinia caerulea & $1.7(0.19)$ & $1.8(0.13)$ & $1.07^{\text {n.s. }}$ & $6.7(0.54)$ & $9.8(0.70)$ & $1.46^{* * *}$ \\
\hline Agrostis canina & $18.8(2.17)$ & $11.0(0.91)$ & $0.59^{* * *}$ & $6.8(0.64)$ & $11.4(0.95)$ & $1.68^{* * *}$ \\
\hline Anthoxanthum odoratum & $23.0(2.03)$ & $13.8(0.49)$ & $0.60 * * *$ & $9.6(0.73)$ & $15.9(0.56)$ & $1.66^{* * *}$ \\
\hline Holcus lanatus & $21.5(1.46)$ & $15.3(2.07)$ & $0.71 *$ & $13.0(0.93)$ & $20.2(2.73)$ & $1.56^{* * *}$ \\
\hline
\end{tabular}

* Initially there was one tiller of each species planted, exept for $C$. davalliana (2-4 tillers). Values are means $( \pm \mathrm{SE}, n=8)$ for the two treatments with full daylight during this period (L and LS) and for those with $12 \%$ or $20 \%$ daylight (S and SL), as well as significance levels from ANOVA for differences between light and shade (see Table 3 for significance levels). The relative response to shading (ratio shade/light) was calculated from the means for light and shade. 
pattern of light availability, and that they appear progressively. In the first year, the morphology of the species responded to the treatments but there were no differences in shoot biomass (neither at community nor at species level). In the second year, the biomass of the communities still did not differ among treatments but the biomass of individual species did. In the third year, finally, light treatments also affected community biomass. Thus, shading treatments caused subtle effects, which appeared gradually (cf. Leps 1999).

There are several reasons for the lack of any significant light effect on community biomass in the first two years. First, light treatments started only after plants had established. The germination and establishment phase is in most species far more shade-sensitive than the growth of established plants (Foster and Gross 1998; Spacková et al. 1998; Schütz and Rave 1999). Second, a light reduction to $20 \%$ daylight does not cause a severe reduction in plant growth in the species investigated here (Edelkraut and Güsewell 2001). At least in the absence of competition, growth is only severely reduced when light availability is reduced to less than 10\% daylight (Ryser and Eek 2000; Kotowski et al. 2001). This corresponds to the level of shading reached in the third year, when treatment effects on community biomass were indeed significant. Third, a possible reduction in biomass production at $20 \%$ daylight was probably compensated for by an increased biomass allocation to shoots (Poorter and Nagel 2000).

The significant effects of shading on community biomass in the third year were probably not due only to the greater shading intensity. Already in the second year, regrowth after the first harvest tended to be better in light than in shade. Shading may have reduced the ability of the plants to regenerate after mowing, probably by increasing the biomass allocation to shoots: this change in allocation would increase the proportion of a plant's total biomass that is removed by the harvest, and would concomitantly reduce the quantity of below-ground reserves that can be mobilised for regrowth. The mobilisation of basal and belowground reserves is essential for the shoot regeneration of plants after cutting (e.g. Thornton 1991), and therefore poorer regeneration is expected in shade. The progressive appearance of shading effects was also related to the change in community composition: the communities were dominated by the three fast-growing grass species in the first two years of the experiment, whereas the Carex species contributed increasingly during the second and third year. Their stronger response to shade (cf. Table 4) resulted in light limitation of community growth. Although the ratio of grasses to Carex decreased with time and was lower in the control plots compared to shaded plots, Simpson's Index did not show any differences between these two light treatments (full shade and control). This was mainly due to high production of $C$. elata, which replaced the primarily dominant position of Holcus lanatus.

The various shading regimes primarily affected the seasonal distribution of biomass production, which was greater during the light phases. In addition there was also an effect on total annual production, especially in the third year: despite the fact that plants in the shading treatments experienced the same reduction in light availability in total, annual production was reduced more by continuous shading than by seasonal or weekly shading. That contrasts with greenhouse experiments where (at same total irradiation) plants grew faster at constant than at pulsed light supply (Sims and Pearcy 1993), and also grew faster when light supply was spread over more hours per day (Poorter and Van der Werf 1998). The difference between those studies and the present one is that our light phases lasted much longer. Plant responses to short light phases ( $<1$ day) are purely physiological (Sims and Pearcy 1993), whereas long light phases might induce morphological responses (cf. Campbell et al. 1991). In this experiment shoot height (in June 2000) was increased more by continuous moderate shade than by weekly alternating (but stronger) shade. We did not determine biomass allocation to roots in this experiment but it is possible that the latter also differed between periodical and continuous shading.

No difference in total production or species composition was found among the three treatments with seasonal or weekly shading, indicating that seasonal shading affects shoot biomass production less than seasonal nutrient pulses (Kielland and Chapin III 1994; Goldberg and Novoplansky 1997; Boeye et al. 1999). This was probably due to the June harvest. The latter prevented a progressive canopy development during the whole season, and thus created similar light 
conditions in both parts of the growing season in the absence of seasonal shading. The June harvests also reduced the phenological differences among species, i.e. growth in the second part of the season depended more on regrowth capacity after mowing than on phenology (Wardle et al. 1999).

Overall, our artificial wetland communities had a rather low shoot biomass production compared with natural rich fen communities (Boeye et al. 1997; Bollens 2000), although nutrient concentrations of the peat were high at our site. This was probably due to the assortment of species, which did not include highly productive tall forbs or grass species. The only truly fast-growing species, Holcus lanatus, was obviously inhibited by water logging in the second year (e.g. van Duren et al. 1997).

The relatively low shoot biomass suggests that root competition was more intense than light competition in this experiment (Twolan-Strutt and Keddy 1996). This - together with the harvesting regime - probably explains why the Carex species could progressively become dominant in the unshaded plots: many experiments with grassland species showed low-productive species to be promoted by regular cutting relative to more productive species, (e.g. Berendse et al. 1992; Schippers et al. 1999; Fransen and De Kroon 2001). The greater tolerance to cutting in Carex species may be due to a short stature, large biomass allocation to roots (Konings et al. 1989) and low root turnover (Aerts and De Caluwe 1995).

\section{Response of individual species}

Based on their responses to the light treatments, the nine species in the experiment can be subdivided into three groups. The most sensitive species were $C$. davalliana, $C$. flacca and $C$. flava, whose shoot biomass differed significantly between the control and shaded treatments in 2001 and 2002. Their shoot height was smallest and least plastic in response to shading of the nine species in the experiment. In a pot experiment (Edelkraut and Güsewell 2001), these species even reduced their shoot height in strong shade (4\% daylight), leading to a low competitive ability in dense and tall vegetation stands (Alonso and Hartley 1998; Naumburg et al. 2001). However, in full daylight these species could compete effectively, probably due to high tissue density and root biomass, which reduce their nutrient losses (Güsewell 1997; Edelkraut and Güsewell 2001). C. davalliana and C. flava are both species from low-productive, open habitats (Landolt 1977), so that their sensitivity to shade was expected; these species were also sensitive to shade in pot experiments (Edelkraut and Güsewell 2001). In contrast, C. flacca occurs in forest understory, where it seems to tolerate moderate shade. In these forest sites, C. flacca grows in nutrient-rich mull humus with few neighbouring herbaceous plants, and it only develops a very restricted root system (S. Güsewell, pers. obs.). This maximises light use efficiency, but in our competitive wetland communities such a response would impair nutrient acquisition. In other words, sensitivity to shade was possibly mediated by root competition in C. flacca (see Cahill 1999).

$C$. elata and $C$. panicea were reduced significantly by shading only in 2002 . Their shoots were taller than those of the three other Carex species, which would increase their ability to compete for light when the latter was limiting. Furthermore, we know from pot experiments that both species are able to maintain a high allocation of biomass to roots in shade (Edelkraut 2004; Güsewell 2005), enabling them to compete for light and nutrients at the same time. This was particularly true of Carex elata, whose biomass strongly increased in the course of the experiment even in the shaded treatments.

Shading did not reduce the four grass species. Three of them (Agrostis, Anthoxanthum, and Holcus) showed a high morphological plasticity in response to shading (lower tiller production and increase in shoot height). The biomass production of these species was maximal in early 2001 and thereafter decreased in all treatments, suggesting that this decrease was mainly due to losses of nutrients and assimilates by cutting and high turnover rates of leaves and roots (Fransen and De Kroon 2001), rather than to shading. Allocation of biomass and assimilates to reserve organs may be less pronounced in the grasses compared to the Carex species, resulting in these higher losses. The lack of any response of Molinia, finally, was related to its poor growth in this experiment. Molinia establishes only slowly (Bollens 2000) and is sensitive to permanent wetness (El-Kahloun et al. 2000), so that the high groundwater levels in 2001 probably inhibited its development in our experiment. 
Although differences in size and morphological plasticity reflected the species' growth responses to shade, these differences were too small to directly cause the differing shade tolerance (see also Corré 1983; Olff 1992). Three of the grasses, Holcus and Anthoxanthum and Agrostis, rapidly produced new tillers in the initial phase of the experiment and therefore showed stronger responses to light treatments compared to the other, slower growing species. Rather than plasticity itself, the effect of plasticity on a plant's performance in shade may differ: Anten and Hirose (1999) proposed that increased shoot height (as induced by shade) enhances the light capture of the tallest species in a canopy but has the opposite effect on shorter species. Accordingly, typical forest floor plants are characterised by low morphological plasticity (Henry and Aarssen 1997; McKenna and Houlé 1999). If shade reduced biomass allocation to roots as we suppose, this would also affect the nine species differently. High biomass allocation to roots in a mown system allows faster re-growth after mowing and probably confers a competitive advantage early in the season (Schippers et al. 1999). Reduced allocation to roots in shade would therefore affect the smaller species more than the taller ones, as smaller species depend particularly on light capture early in the season (or after harvest; Anten and Hirose 1999). Thus, even though shade reduced light availability for all species in the experiment, it may have selectively disadvantaged the smaller Carex species by inducing plastic responses, which eventually reduced their competitive ability relative to the taller species.

\section{Conclusions}

Although experimental shading did not affect the aboveground biomass and species composition of the wetland communities in the first year, it clearly determined their further development. After three growing seasons, the shaded communities (especially those that were shaded continuously) were dominated by grasses, whereas the unshaded communities were dominated by Carex species. We propose that a high allocation of nutrients and biomass to roots reduced nutrient losses of the Carex species during harvest compared to the grasses and thus contributed to their long-term advantage in full light. Furthermore, our results and results from other growth experiments with the same species indicate that the reduced competitive ability of the Carex species in shade was not due to their high allocation to roots nor to a lack of morphological plasticity. We rather suspect that in shaded Carex plants, an increased biomass allocation to shoots resulted in reduced nutrient acquisition, stronger damage from cutting, and eventually, reduced ability to compete for light. We encourage further experiments combining different shading regimes with different mowing regimes to verify these suggestions and test the role of biomass allocation for competitive ability in mown and shaded communities.

\section{Acknowledgements}

We are most thankful to Dieter Ramseier and the Stiftung Seebachtal, who made the site available for this experiment and provided the seeds as well as valuable advice and support. We also thank Peter J. Edwards for advice on the experiment and R. Aerts for helpful comments on the manuscript. Phillipp Hafliger, Hanspeter Suter and Mark van Kleunen provided substantial help in establishing the field plots, and Claude Théato, Regula Ott and Kathrin Jaag efficiently helped in maintaining the experiment and collecting data. The research was funded through a grant from the Swiss Federal Institute of Technology, Zürich.

\section{References}

Aerts R. and De Caluwe H. 1995. Interspecific and intraspecific differences in shoot and leaf life-span of 4 Carex species which differ in maximum dry-matter production. Oecologia 102: $467-477$.

Alonso I. and Hartley S.E. 1998. Effects of nutrient supply, light availability and herbivory on the growth of heather and three competing grass species. Plant Ecol. 137: 203-212.

Anten N.P.R. and Hirose T. 1999. Interspecific differences in above-ground growth patterns result in spatial and temporal partitioning of light among species in a tall-grass meadow. J. Ecol. 87: 583-597.

Belcher J.W., Keddy P. and Twolan-Strutt L. 1995. Root and shoot competition intensity along a soil depth gradient. J. Ecol. 83: 673-682.

Berendse F., Elberse W.T. and Geerts R.H.M.E. 1992. Competition and nitrogen loss from plants in grassland ecosystems. Ecology 73: 46-53. 
Boeye D., Verhage B., Van Haesebroeck V. and El-Kahloun M. 1999. Phosphorous fertilization in a phosphorous-limitated fen: effects of timing. Appl. Veg. Sci. 2: 71-78.

Boeye D., Verhagen B., Van Haesebroeck V. and Verheyen R.F. 1997. Nutrient limitation in species-rich lowland fens. J. Veg. Sci. 8: 415-424.

Bollens U. 2000. Effects of nutrient inputs and water regime on wetland vegetation and the performance of wetland species. Dissertation ETH No. 13 560, ETH, Zürich.

Cahill J.F. 1999. Fertilization effects on interactions between above- and belowground competition in an old field. Ecology 80: 466-480.

Campbell B.D., Grime J.P., Mackey J.M.L. and Jalili A. 1991. The quest for a mechanistic understanding of resource competition in plant communities: the role of experiments. Funct. Ecol. 5: 241-253.

Corré W.J. 1983. Growth and morphogenesis of sun and shade plants. I. The influence of light intensity. Acta Bot. Neerland. 32: $49-62$.

Edelkraut K. and Güsewell S. 2001. Effects of light and nutrient supply on the growth and competitive ability of five Carex species. Bull. Geobot. Inst. ETH 67: 41-56.

Edelkraut K. 2004. Interacting effects of resources and competition on the growth of wetland plants. Dissertation ETH No. 15250, ETH Zürich.

Eek L. and Zobel K. 1997. Effects of additional illumination and fertilization on seasonal changes in fine-scale grassland community structure. J. Veg. Sci. 8: 225-234.

El-Kahloun M., Boeye D., Verhagen B. and Van Haesebroeck V. 2000. A comparison of the nutrient status of Molinia caerulea and neighbouring vegetation in a rich fen. Belg. J. Bot. 133: $91-102$.

Foster B. 2000. Competition at the population level along a standing crop gradient: a field experiment in successional grassland. Plant Ecol. 151: 171-180.

Foster B.L. and Gross K.L. 1998. Species richness in a successional grassland: Effects of nitrogen enrichment and plant litter. Ecology 79: 2593-2602.

Fransen B. and De Kroon H. 2001. Long-term disadvantages of selective root placement: root proliferation and shoot biomass of two perennial grass species in a 2 year experiment. J. Ecol. 89: 711-722.

Goldberg D.E. and Novoplansky A. 1997. On the relative importance of competition in unproductive environments. J. Ecol. 85: 409-418.

Güsewell S. 1997. Evaluation and management of fen meadows invaded by Phragmites australis. Diss. ETH No 12'428, Zürich.

Güsewell S. and Edwards P.J.E. 1999. Shading by Phragmites australis: a threat for species-rich fen meadows?. Appl. Veg. Sci. 2: $61-70$.

Güsewell S. 2005. Responses of wetland graminoids to the relative supply of nitrogen and phosphorus. Plant Ecol. 176: 35-55.

Henry H. and Aarssen L. 1997. On the relationship between shade tolerance and shade avoidance strategies in woodland plants. Oikos 80: 575-582.

Hess H.E., Landolt E. and Hirzel R. 1991. Bestimmungsschlüssel zur Flora der Schweiz und angrenzender Gebiete 3rd ed. Birkhäuser, Basel.

Hirose T. and Werger M.J. 1995. Canopy structure and photon flux partitioning among species in a herbaceous plant community. Ecology 76: 466-474.
Jensen K. and Schrautzer J. 1999. Consequences of abandonment for a regional fen flora and mechanisms of successional change. Appl. Veg. Sci. 2: 79-88.

Keddy P.A. 1989. Effects of competition from shrubs on herbaceous wetland plants: a 4-year field experiment. Can. J. Bot. 67: 708-716.

Kielland K. and Chapin F.S. III 1994. Phosphate uptake in arctic plants in relation to phosphate supply: the role of spatial and temporal variability. Oikos 70: $443-448$.

Konings H., Koot E. and Wolf A.T. 1989. Growth characteristics, nutrient allocation and photosynthesis of Carex species from floating fens. Oecologia 80: 111-121.

Kotowski W., van Andel J., van Diggelen R. and Hogendorf J. 2001. Responses of fen plant species to groundwater level and light intensity. Plant Ecol. 155: 147-156.

Landolt E. 1977. Ökologische Zeigerwerte zur Schweizer Flora. Veröff. Geobotan. Inst. ETH, Stiftung Rübel, Zürich 64: 1 208.

Leps J. 1999. Nutrient status, disturbance and competition: an experimental test of relationships in wet meadow copy. J. Veg. Sci. 10: 219-230.

Liira J. and Zobel K. 2000. Vertical structure of a species-rich grassland canopy, treated with additional illumination, fertilization and mowing. Plant Ecol. 146: 185-195.

McKenna M. and Houlé G. 1999. The effect of light on the growth and reproduction of Floerkea proserpinacoides. New Phytol. 141: 99-108.

Naumburg E., De Wald L.E. and Kolb T.E. 2001. Shade responses of five grasses native to southwestern US Pinus ponderosa forests. Can. J. Bot.-Rev. Can. Bot. 79: 1001-1009.

Olff H. 1992. Effects of light and nutrient availability on dry matter and $\mathrm{N}$ allocation in six successional grassland species: testing for resource ratio effects. Oecologia 89: 412-421.

Poorter H. and Nagel O. 2000. The role of biomass allocation in the growth response of plants to different levels of light, $\mathrm{CO} 2$, nutrients and water: a quantitative review. Aust. J. Plant Physiol. 27: 595-607.

Poorter H. and Van der Werf A. 1998. Is inherent variation in RGR determined by LAR at low irradiance and by NAR at high irradiance? A review of herbaceous species. In: Lambers H., Poorter H. and Van Vuuren M.M.I. (eds.), Inherent Variation in Plant Growth. Physiological Mechanisms and Ecological Consequences, Backhiys Publishers, Leiden, pp. 309-336.

Rajaniemi T.K. 2002. Why does fertilization reduce plant species diversity? Testing three competition-based hypotheses. J. Ecol. 90: 316-324.

Ryser P. and Eek L. 2000. Consequences of phenotypic plasticity vs. interspecific differences in leaf and root traits for acquisition of aboveground and belowground resources. Am. J. Bot. 87: 402-411.

Schieving F. and Poorter H. 1999. Carbon gain in a multispecies canopy: the role of specific leaf area and photosynthetic nitrogen-use efficiency in the tragedy of the commons. New Phytol. 143: $201-211$.

Schippers P., Snoeijing I. and Kropff M.J. 1999. Competition under high and low nutrient levels among three grassland species occupying different positions in a successional sequence. New Phytol. 143: 547-559.

Schütz W. and Rave G. 1999. The effect of cold stratification and light on the seed germination of temperate sedges 
(Carex) from various habitats and implications for regenerative strategies. Plant Ecol. 144: 215-230.

Sims D.A. and Pearcy R.W. 1993. Sunfleck frequency and duration affects growth rate of the understorey plant, Alocasia macrorrhiza. Funct. Ecol. 7: 683-689.

Spacková I., Kotorová I. and Leps J. 1998. Sensitivity of seedling recruitment to moss, litter and dominant removal in an oligotrophic wet meadow. Folia Geobot. Phytotaxon. 33: $17-30$.

Stuefer J.F. and Huber H. 1998. Differential effects of light quantity and spectral light quality on growth, morphology and development of two stoloniferous Potentilla species. Oecologia 117: 1-8.

Thornton B. 1991. Effect of nutrition on the short-term response of Molinia caerulea to defoliation. Ann. Bot. 68: 569-576.

Twolan-Strutt L. and Keddy P.A. 1996. Above- and belowground competition intensity in two contrasting wetland plant communities. Ecology 77: 259-270.

van Duren I., Pegtel D., Aerts B. and Inberg J. 1997. Nutrient supply in undrained and drained Calthion meadows. J. Veg. Sci. 8: $829-838$.
Wardle D., Bonner K., Barker G., Yeates G., Nicholson K., Bardgett R., Watson R. and Ghani A. 1999. Plant removals in perennial grassland: vegetation dynamics, decomposers, soil biodiversity, and ecosystem properties. Ecol. Monogr. 69: $535-568$.

Weihe P.E. and Neely R.K. 1997. The effects of shading on competition between purple loosestrife and broad-leaved cattail. Aquat. Bot. 59: 127-138.

Wheeler B.D. and Shaw S.C. 1991. Above-ground crop mass and species richness of the principal types of herbaceous richfen vegetation of lowland England and Wales. J. Ecol. 79: 285-301.

Yoshie F. 1995. Interhabitat variation in growth characteristics of temperate herbaceous perennials. Can. J. Bot. 73: $735-745$.

Zobel K. 2001. On the species-pool hypothesis and on the quasi-neutral concept of plant community diversity. Folia Geobot. Phytotaxon. 36: 3-8. 